Penelitian

\title{
Pengaruh Pemberian PGF2a terhadap Peningkatan Kualitas Spermatozoa Kambing Boerka
}

\author{
Effect of PGF2 $\alpha$ Administration on the Quality \\ of Boerka Goat Spermatozoa
}

\author{
Amalia Sutriana', Fuza Khoiriah'², Husnurrizal ${ }^{3}$, Tongku Nizwan Siregar ${ }^{{ }^{*}}$, Rasmaidar', Herrialfian ${ }^{4}$ \\ 'Laboratorium Farmakologi, Fakultas Kedokteran Hewan, Universitas Syiah Kuala, Indonesia \\ ${ }^{2}$ Program Pendidikan Dokter Hewan, Fakultas Kedokteran Hewan, Universitas Syiah Kuala, Indonesia \\ ${ }^{3}$ Laboratorium Reproduksi, Fakultas Kedokteran Hewan, Universitas Syiah Kuala, Indonesia \\ ${ }^{4}$ Laboratorium Biokimia, Fakultas Kedokteran Hewan, Universitas Syiah Kuala, Indonesia \\ *Penulis untuk korespondensi: siregar@unsyiah.ac.id \\ Diterima 4 Juni 2020, Disetujui 8 Agustus 2020
}

\begin{abstract}
ABSTRAK
Usaha untuk meningkatkan produktivitas ternak kambing Boerka di antaranya dengan melakukan inseminasi buatan (IB). Untuk meningkatkan kualitas spermatozoa yang akan digunakan untuk IB maka diberikan hormon prostaglandin F2 alfa (PGF2a). Penelitian ini bertujuan mengetahui pengaruh pemberian PGF2 $a$ terhadap peningkatan motilitas spermatozoa kambing Boerka. Dalam penelitian digunakan 3 ekor kambing Boerka yang berumur $\pm 2-3$ tahun. Pelaksanaan perlakuan dirancang menggunakan pola latin square 3 × 3 sehingga hewan akan menerima suntikan P1 (1,5

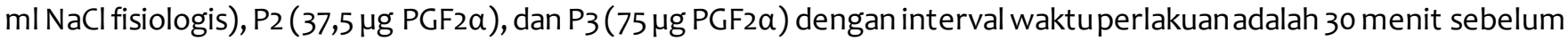
koleksi semen. Sampel semen dikoleksi dengan menggunakan vagina buatan dan diamati warna, konsistensi, volume, konsentrasi, motilitas, viabilitas, dan motilitas spermatozoa. Motilitas spermatozoa diamati setelah 4 jam di dalam refrigerator. Data warna dan konsistensi semen dilaporkan secara deskriptif, sedangkan volume, motilitas semen segar, dan motilitas spermatozoa setelah 4 jam di dalam refrigerator dianalisis dengan analisis varian pola bujur sangkar latin (RSBL) yang dilanjutkan dengan uji Duncan. Hasil pengamatan menunjukkan bahwa warna dan konsistensi semen yang dikoleksi pada semua kelompok perlakuan adalah krem dengan konsistensi kental. Rataan ( \pm SD) volume semen; konsentrasi spermatozoa (10\% $/ \mathrm{ml})$; motilitas semen segar (\%); dan motilitas semen setelah penyimpanan pada P1 vs $\mathrm{P} 2$ vs $\mathrm{P} 3$ masing-masing adalah $0,90 \pm 0,4$ vs $0,70 \pm 0,3$ vs $0,90 \pm 0,3 \mathrm{ml}(P>0,05) ; 2303,33 \pm 327,15$ vs $2336,67 \pm 332,91$ vs $2576,67 \pm 261,02$ ( $P>0,05) ; 84,00 \pm 5,1$ vs $73,33 \pm 11,54$ vs $80,00 \pm 0,0 \%$ ( $P>0,05) ; 63,67 \pm 4,5$ vs $53,33 \pm 4,7$ vs $66,67 \pm 2,2 \%$ $(\mathrm{P}<0,05)$. Disimpulkan bahwa pemberian $75 \mu \mathrm{g}$ PGF2a dapat meningkatkan motilitas spermatozoa kambing Boerka setelah penyimpanan dalam regrigerator selama 4 jam.
\end{abstract}

Kata kunci : kambing Boerka, PGF2a, spermatozoa, motilitas

\section{ABSTRACT}

One of the efforts to increase the productivity of Boerka goats is through artificial insemination. Generally, PGF2a is given in order to improve the quality and quantity of spermatozoa success of AI. The objective of this study was to determine the effect of PGF2 $\alpha$ administration on the spermatozoa motility of Boerka goats. Three Nubian goats aged $\pm 2-3$ years were used in this study. This research was designed using $3 \times 3$ latin square design in which each goat received injection of $\mathrm{NaCl}$ as a

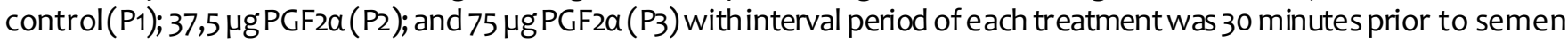
collection. Semen samples were collected using artificial vagina and the color, volume, and motility of spermatozoa were observed. Semen motility was observed after 4 hours in refrigerator. The data of semen quality (color and consistency) were reported descriptively, whereas semen volume, motility, concentration, and motility after 4 hours in refrigeration were analyzed using analysis of variance and continued with Duncan test. The result showed that the color of the semen collected in all treatment groups was creamy with thick consistency. The mean $( \pm \mathrm{SD})$ semen volume (ml), spermatozoa concentration $\left(10^{6} / \mathrm{mL}\right)$, fresh semen motility(\%), and semen motility after 4 hours in refrigerator in groups (\%) $\mathrm{P} 1$ vs $\mathrm{P}_{2}$ vs $\mathrm{P}_{3}$ were $0.90 \pm 0.5$ vs $0.70 \pm 0.3$ vs $0.90 \pm 0.3 \mathrm{ml} ; 2303.33 \pm 327.15$ vs $2336.67 \pm 332.91$ vs $2576.67 \pm 261.02(P>0,05) ; 84,00 \pm 5,1$ vs $73,33 \pm 11,54$ vs $80,00 \pm 0,0(P>0,05) ; 63,67 \pm 5,5$ vs $53,33 \pm 5,7$ vs $66,67 \pm 2,8(P<0,05)$, respectively. It can be concluded that the administration of 75 ug PGF2 $\alpha$ increase the spermatozoa motility in Boerka goats after 4 hours of storage in refrigerator.

Keywords : Boerka goat, PGF2a, spermatozoa, motility 


\section{PENDAHULUAN}

Kambing Boerka merupakan salah satu jenis ternak ruminansia yang banyak diminati oleh masyarakat untuk dipelihara dan dijadikan sebagai kepentingan produksi (Ismail, 2009). Kambing Boerka adalah hasil persilangan antara kambing Boer dengan kambing Kacang. Kambing Kacang memiliki kualitas kesuburanyang baik dengan adaptasi terhadap lingkungan sekitar (Ginting \& Mahmilia, 2008), sedangkan kambing Boer merupakan salah satu jenis ternak kambing pedaging yang mempunyai performa tubuh yang kompak, pertumbuhannya yang cepat, serta kualitas karkas yang baik (Nasich, 2011).

Usaha untuk meningkatkan produktivitas ternak kambing telah banyak dilakukan, di antaranya dengan penyediaan bibit unggul, pejantan yang berkualitas dan penerapan teknologi reproduksi seperti inseminasi buatan (IB). Inseminasi buatan merupakan langkahyang tepat untuk mengadakan bibit unggul, namun keberhasilan IB masih belum optimal dan perlu ditingkatkan. Salah satu faktor yang memengaruhi keberhasilan IB pada kambing adalah kualitas dan kuantitas semen yang digunakan (Saifudin et al., 2018).

Dalam pelaksanaan IB, semen yang digunakan adalah semen beku yang telah diencerkan dan selanjutnya dibekukan pada suhu tertentu yang bertujuan menghambat aktivitas dan metabolisme spermatozoa (Hoesni, 2013). Namun dalam pelaksaanan IB, seringkali terjadi kegagalan kebuntingan yang disebabkan rendahnya kualitas semen. Dalam beberapa tahun terakhir, banyak penelitian telah dilakukan untuk meningkatkan kualitas dan kuantitas spermatozoa, salah satunya adalah dengan penggunaan hormon. Sieme et al. (2004) melaporkan bahwa pemberian gonadotropin releasing hormone $(\mathrm{GnRH})$ mampu meningkatkan tingkah laku seksual dan mengoptimalkan kualitas spermatozoa beku (motilitas progessif, integritas membran, persentase spermatozoa hidup, dan resistensi osmotik) pada kuda yang fertil. Injeksi hormon oksitosin sebelum dilakukan koleksi semen pada domba juga diketahui sangat bermanfaat dalam meningkatkan jumlah spermatozoa tanpa menggangu kualitas semen segar dan semen bekuthawed (El-Badry et al., 2013).

Penggunaan prostaglandin $\mathrm{F} 2$ alfa (PGF2a) untuk meningkatkan kualitas spermatozoa masih menjadi polemik. Pada beberapa penelitian terdahulu dilaporkan bahwa penyuntikan PGF2a secara signifikan meningkatkan volume semen, konsentrasi sel sperma, dan total jumlah spermatozoa per ejakulasi pada domba (El-Badry et al., 2013), sapi jantan (Masoumi et al., 2011), kerbau (Ibrahim, 1988), kuda (Kreider et al., 1981), kelinci (Hafs et al., 1974), dan anjing (Hess, 2002). Namun pada babi, pemberian PGF2a tidak memengaruhi kualitas spermatozoa (Levis \& Reicks, 2005). Perbedaan hasil ini di samping karena perbedaan jenis hewan diduga juga dipengaruhi oleh perbedaan breed atau galur (Badr, 1975).

Peningkatan kualitas spermatozoa setelah injeksi hormon sangat menguntungkan jika penurunan kualitas semen pada masa kriopreservasi dan thawing dapat dihindari (Hess, 2002). Masoumi et al. (2011) menyatakan bahwa pemberian PGF2a pada sapi jantan sebelum ejakulasi tidak memengaruhi motilitas spermatozoa bekucair.

El-Badry et al. (2013) melaporkan bahwa penyuntikan hormon PGF pada domba menunjukkan bahwa penyuntikan hormon PGF2a menghasilkan peningkatan volume semen yang signifikan, konsentrasi sel sperma dan jumlah total spermatozoa per ejakulasi. Sejauh ini laporan tentang penggunaan PGF2a terhadap nilai spermatozoa pada ternak lain sudah banyak diteliti namun pada kambing khususnya pada kambing hasil persilangan yaitu Boerka belum tersedia. Oleh karena itu perlu dilakukan penelitian untuk mengevaluasi nilai spermatozoa pada kambing Boerka setelah injeksi PGF2a.

\section{BAHAN DAN METODE}

Penelitian ini dilaksanakan di UPT. Hewan Coba dan Laboratorium Reproduksi Fakultas Kedokteran Hewan, Universitas Syiah Kuala yang dilakukan pada bulan Desember 2019-Februari 2020.

\section{Bahan dan Alat}

Penelitian ini menggunakan rancangan pola latin square $3 \times 3$. Hewan percobaan diberikan suntikan $1,5 \mathrm{ml} \mathrm{NaCl}$ fisiologis sebagai kontrol (P1); $37,5 \mu \mathrm{g}$ PGF2 $\alpha\left(\mathrm{P}_{2}\right.$, Sincrovall ${ }^{\circledR}$ Mevet. MPA Veterinary Medicines and Additives-Spain), dan $75 \mu \mathrm{g}$ PGF2a (P3). Skema perlakuan yang diberikan pada masing-masing hewan disajikan pada Tabel 1. Dalam penelitian ini digunakantiga ekor kambing Boerka jantan berumur $\pm 2-3$ tahun. 


\section{Penampungan Semen}

Semen dikoleksi menggunakan vagina buatan. Sebelum digunakan, vagina buatan, karet corong dan tabung penampung semen dibuat dalam kondisi kering dan bersih untuk mencegah kontaminasi pada semen. Interval antar perlakuan adalah satu minggu. Koleksi semen dilakukan 30 menit setelah penyuntikan PGF2a sesuai petunjuk Olfati et al. (2013). Pola penyuntikan sampel disajikan pada Tabel 1.

\section{Pemeriksaan Kualitas Semen}

Segera setelah ditampung, semen langsung dievaluasi secara makroskopis dan mikroskopis. Pemeriksaan makroskopis meliputi pemeriksaan volume, warna dan konsistensi semen (Herdis, 2017). Pemeriksaan mikroskopis meliputi pemeriksaan motilitas, konsentrasi, dan viabilitas spermatozoa (Herdis, 2017).

\section{Konsentrasi Spermatozoa}

Konsentrasi spermatozoa dihitung menggunakan pipet haemocytometer dan kamar hitung Neubauer. Semen dihisap sampai skala 0,5 kemudian ditambahkan dengan larutan $\mathrm{NaCl} 3 \%$ dan dihisap sampai mencapai angka 101. Kemudian larutan dihomogenkan membentuk angka 8 selama 2-3 menit, dibuang beberapa tetes. Sampel diisikan ke dalam kamar hitung Neubauer yang telah ditutup menggunakan gelas penutup. Kemudian diamati di bawah mikroskop dengan pembesaran $40 \times 10$. Penghitungan spermatozoa dilakukan pada lima kotak besar. Konsentrasi spermatozoa yang didapatkan adalah $\mathrm{Y} \times 5 \times 10^{6}$ ( $\mathrm{Y}=$ jumlah spermatozoa pada 5 kotak) (Mughniati et al., 2018).

\section{Motilitas Spermatozoa}

Motilitas spermatozoa diamati dengan meneteskan satu tetes spermatozoa diatas gelas objek dan ditambahkan dengan satu tetes $\mathrm{NaCl}$ fisiologis, kemudian diamati dibawah mikroskop dengan pembesaran $10 \times 40$. Jumlah sperma motil dihitung berdasarkan pergerakan spermatozoa yaitu progresif cepat (A), progresif lambat (B), sirkuler (C), dan fibrasi (D). Penentuan persentase motilitas spermatozoa menggunakan rumus yang ditetapkan oleh WHO (1999), yakni:

$\%$ motilitas $=\frac{A}{A+B+C+D} \times 100 \%$

\section{Pembuatan Bahan Pengencer}

Pembuatan pengencer Andromed (OptiXcell 2 IMV-Technologies)dilakukan dengan mencampurkan Andromed dan aquades dengan perbandingan 1:4 atau ( $5 \mathrm{ml}$ Andromed : $20 \mathrm{ml}$ aquades) sampai homogen lalu disimpan di dalam inkubator bersuhu $36-37^{\circ} \mathrm{C}$ (Astuti, 2017). Jumlah pengencer yang dibutuhkan untuk mengencerkan semen dihitung berdasarkan rumus dibawah ini.

Jumlah pengencer

$=\frac{\text { Volume akhir } \mathrm{x} \text { motilitas } \mathrm{x} \text { konsentrasi } \mathrm{x} \text { volume straw }}{\text { Konsentrasi spermatozoa per straw }}$

\section{Pengenceran Semen}

Pengencer yang telah dibuat dicampur dengan sperma segar menggunakan gelas ukur, lalu dimasukkan ke dalam lemari pendingin selama 4 jam .

\section{Analisis Data}

Data hasil pemeriksaan kualitas semen dianalisis dengan analisis pola bujur sangkar latin (RSBL) yang dilanjutkan dengan menggunakan uji Duncan.

Tabel 1 Pola perlakuan terhadap hewan coba

\begin{tabular}{cccc}
\hline \multirow{2}{*}{ Minggu } & \multicolumn{3}{c}{ Perlakuan } \\
\cline { 2 - 4 } & $\mathrm{I}$ & $\mathrm{II}$ & $\mathrm{III}$ \\
\hline 1 & $\mathrm{P} 1$ & $\mathrm{P} 2$ & $\mathrm{P} 3$ \\
2 & $\mathrm{P} 2$ & $\mathrm{P} 3$ & $\mathrm{P} 1$ \\
3 & $\mathrm{P} 3$ & $\mathrm{P} 1$ & $\mathrm{P} 2$ \\
\hline
\end{tabular}

Keterangan: $P_{1}=1,5 \mathrm{ml} \mathrm{NaCl}$ fisiologis; $\mathrm{P}_{2}=37,5 \mu \mathrm{g} \quad \mathrm{PGF}_{2} \alpha ; \mathrm{P}_{3}=75 \mu \mathrm{g} \mathrm{PGF}_{2} \alpha$ 
HASIL

Pengamatan kualitas semen segar secara makroskopis dan mikroskopis dimaksudkan untuk mengetahui layak tidaknya semen segar tersebut diproses lebih lanjut dan untuk menentukan kadar pengenceran semen. Warna dan konsistensi semen pada semua perlakuan memperlihatkan warna krem dan konsistensi kental. Kondisi tersebut sesuai dengan pendapatLestari et al. (2014) yang menyatakan bahwa warna semen dan konsistensi normal pada kambing yaitu putih susu sampai krem, dengan konsistensi semen adalah encer hingga kental. Hasil pemeriksaan volume, konsentrasi, dan motilitas spermatozoa kambing Boerka setelah pemberian PGF2a pada ketiga kelompok perlakuan disajikan pada Tabel 2.

\section{PEMBAHASAN}

Pada Tabel 2 terlihat bahwa rata-rata volume semen kambing Boerka berkisar antara 0,70-0,90 $\mathrm{ml}$. Hasil penelitian ini sesuai dengan pendapat Hartono (2010) bahwa volume semen kambing Boerka yaitu $0,93 \mathrm{ml}$ per ejakulat. Hasil analisis varian menunjukkan bahwa pemberian hormon PGF2a tidak berpengaruh nyata $(P>0,05)$ terhadap peningkatan volume semen. Hasilyang diperoleh pada penelitian ini sesuai dengan laporan Sari et al. (2019), bahwa pemberian PGF2a tidak memengaruhi volume semen sapi bali. Namun Masoumi et al. (2008) melaporkan hal yang sebaliknya, pemberian PGF2a berpengaruh terhadap peningkatan volume semen sapi Iranian Holstein $(6,8 \pm 0,2$ $\mathrm{ml}$ ) dibandingkan dengan kelompok kontrol $(5,7 \pm 0,2 \mathrm{ml})$. Secara umum beberapa penelitian melaporkan peningkatan volume semen setelah pemberian PGF2a (Hashizume dan Niwa 1984: Masoumi et al., 2008).
Peningkatan volume semen akibat pemberian PGF2a kemungkinan berkaitan dengan pengaruh PGF2a terhadap peningkatan kontraksi otot polos epididimis dan kapsul testis sehingga jumlah sperma dan cairan glandula asesoris lebih banyak diejakulasikan (Henney et al., 1990; Masoumi et al., 2008). Penelitian ini tidak dapat menjelaskan kegagalan meningkatkan volume semen setelah pemberian PGF2a, namun diduga berkaitan dengan dosis dan metode pemberian. Hashizume dan Niwa (1984) dapat meningkatkan volume semen babi dengan memberikan $12 \mathrm{mg}$ PGF2a selama 28 hari dengan interval 3 hari dan interval pemberian dan koleksi adalah 1 jam. Masoumi et al. (2008) memberikan dosis yang lebih besar yakni $250 \mathrm{mg}$ cloprostenol selama 2 bulan dengan interval koleksi adalah 30 menit setelah pemberian dan koleksi dilakukan 2 kali seminggu. Sampel sapi yang digunakan juga berasal dari sapi dengan libido yang rendah. Kemungkinan pemberian tunggal tidak akan mampu meningkatkan volume semen. Kondisi ini sama seperti laporan Sari et al. (2019), bahwa pemberian PGF2a tidak memengaruhi volume semen sapi bali dengan pemberian tunggal dengan waktu koleksi 30 menit setelah pemberian PGF2a.

Warna, konsistensi, dan konsentrasi semen saling berhubungan erat satu sama lain. Semakin kental semen yang dihasilkan, maka konsentrasi semakin tinggi dan warna akan semakin pekat (Sujoko et al., 2009). Hasil penelitian ini menunjukkan bahwa pemberian hormon PGF2a tidak berpengaruh nyata $(P>0,05)$ terhadap konsentrasi spermatozoa. Hasil yang sama juga dilaporkan oleh Armansyah et al. (2018), Sari et al. (2019), dan Kozink et al. (2002) masing-masing padakambing Kacang, sapi bali, dan babi, , namun tidak sesuai dengan laporan Olfati et al. (2013), Hashizume dan Niwa (1984), dan Azawi et al. (2011) masing-masing pada domba cross-breed, babi, dan domba Awassi. Perbedaan respons yang

Tabel 2 Hasil pemeriksaan kualitas semen (rataan \pm SD) pada kambing Boerka setelah pemberian PGF2 $\alpha$

\begin{tabular}{lccc}
\hline \multirow{2}{*}{ Kualitas Semen } & \multicolumn{3}{c}{ Kelompok Perlakuan } \\
\cline { 2 - 4 } & $\mathrm{P}_{1}(\mathrm{NaCl} 1,5 \mathrm{ml})$ & $\mathrm{P} 2(37,5 \mu \mathrm{g}$ PGF2a $)$ & $\mathrm{P} 3(75 \mu \mathrm{g}$ PGF2a $)$ \\
\hline Volume & $0,90 \pm 0,4^{\mathrm{b}}$ & $0,70 \pm 0,3^{\mathrm{a}}$ & $0,90 \pm 0,3^{\mathrm{b}}$ \\
Konsentrasi & $2303,33 \pm 327,15^{\mathrm{b}}$ & $2336,67 \pm 332,91^{\mathrm{b}}$ & $2576,67 \pm 261,02^{\mathrm{a}}$ \\
Motilitas semen segar & $84,00 \pm 5,1^{\mathrm{b}}$ & $73,00 \pm 11,54^{\mathrm{a}}$ & $80,00 \pm 0,0^{\mathrm{b}}$ \\
Motilitas setelah penyimpanan & $63,67 \pm 4,5^{\mathrm{b}}$ & $53,33 \pm 4,7^{\mathrm{a}}$ & $66,67 \pm 2,2^{\mathrm{c}}$ \\
\hline
\end{tabular}

Keterangan: ${ }^{a, b, c}$ Superkrips yang berbeda pada baris yang sama menunjukkan perbedaan yang nyata $(P<0,05)$ 
diperoleh dari penggunaaan PGF2a untuk meningkatkan kualitas semen kemungkinan berkaitan dengan libido awal, genetik, spesies, usia hewan, PGF2a analog dan dosis yang diberikan (Masoumi et al., 2008).

Data hasil pemeriksaan motilitas kambing Boerka pada periode yang berbeda disajikan pada Tabel 2 . Nilai motilitas (\%) semen segar pada kelompok P1; P2; dan P3 masing-masing adalah 84,00 $\pm 5,1$; $73,00 \pm 11,54 ;$ dan $(P<0,05)$. Nilai motilitas ini kemudian menjadi turun setelah penyimpanan dengan motilitas (\%) pada kelompok P1; P2; dan P3 masing-masing adalah 63,67 $\pm 4,5 ; 53,33 \pm 4,7$; dan $66,67 \pm 2,2(P<0,05)$. Dari hasil analisis diketahui bahwa pemberian $75 \mu \mathrm{g}$ PGF2a mampu mempertahankan motilitas spermatozoa. Peningkatan motilitas ini kemungkinan karena PGF2a mampu mempertahankan penurunan motilitas yang terjadi akibat proses penyimpanan. Hasil penelitian ini sejalan dengan laporan Siregar et al. (2014) dan Herawati \& Widiarso (2003) bahwa pemberian PGF dapat meningkatkan motilitas massa spermatozoa. Menurut Schlegel et al. (1981), PGF2a berperan dalam meningkatkan motilitas sperma. Hal ini dibuktikan dengan inaktivasi PGF2a pada sperma melalui inkubasi dengan prostaglandin 15hydroxydehydrogenase mengakibatkan penurunan motilitas sperma.

Herawati \& Widiarso (2003) melaporkan bahwa penambahan 2,0 mg PGF2a dapat meningkatkan motilitas spermatozoa kambing sebelum diencerkan. Peningkatan motilitas spermatozoa tersebut disebabkan karena PGF2a dapat mengaktifkan elemen kontraktil spermatozoa yaitu lapisan serabut yang mengelilingi acronema sentral dari bagian utama spermatozoa. Gottlieb et al. (1988) melaporkan bahwa PGF2a berperan penting dalam meregulasi motilitas spermatozoa dengan cara memediasi kandungan adenosine triphosphate (ATP) di dalam spermatozoa.

Menurut Bygdeman et al. (1985), PGF2a yang terdapat dalam plasma semen berperan dalam merangsang aktivitas kinetik dan motilitas spermatozoa saat ejakulasi. Namun demikian, mekanisme pasti peningkatan motilitas setelah pemberian secara in vivo belum dapat dijelaskan, sebab beberapa argumen yang ada (Schlegel et al., 1981; Gottlieb et al., 1988) cenderung lebih sesuai ketika PGF2a diberikan secara in vitro (ke dalam pengencer) seperti yang telah dibuktikan oleh Prestiya et al. (2020).

Disimpulkan bahwa pemberian $75 \mu \mathrm{g}$ PGF2a dapat meningkatkan motilitas spermatozoa kambing
Boerka setelah penyimpanan dalam refrigerator selama 4 jam. Disarankan untuk penelitian selanjutnya dilakukan dengan cara mengukur motilitas setelah proses pembekuan dan menguji pemberian PGF2a secara in vitro ke dalam pengencer.

"Penulis menyatakan tidak ada konflik kepentingan dengan pihak-pihak yang terkait dalam penelitian ini".

\section{DAFTAR PUSTAKA}

Armansyah T, Barat ERP, Handini CVR, Aliza D, Sutriana A, Hamdan $H$, Panjaitan B, Sayuti A, Siregar TN. 2018. Concentration and motility of spermatozoa and testosterone level of kacang goat after seminal vesicle extract administration. Open Veterinary Journal 8(4): 406-410.

Astuti ME. 2017. Pengaruh penambahan sari buah tomat (Solanum lycopersium) sebagai pengencer alami terhadap kualitas penyimpanan spermatozoa sapi bali (Bos sondaicus). Jurnal Bionature 18(2): 129-139.

Azawi OI, Al-Khashab ANIM, AI-Kadoo NNA. 2011. Study on the effect of prostaglandin F2a Treatment on semen characteristics and enzymatic activities of Awassi rams in breeding and non breeding seasons. Research Opinion in Animal and Veterinary Science 1(5): 318-324.

Badr FM. 1975. Prostaglandin levels in $t$ issues of the male reproductive system in strains of mice. Endocrinology 96: 540-543.

Bygdeman M, Bendvold E, Gottlieb C, Svanborg K, Eneroth P. 1985. Prostaglandins and male fertility. Advanced Prostaglandin Tromboxane Leukot Reserarch. 15: 609-611.

El-Badry DA, Gabry FI, Shaker MH. 2013. The effect of oxytocin prostaglandin F2 alfa or GnRH injection on fresh and frozen-thawed semen characteristic of rams. Assiut of Veterinary Medicine Journal 59(138): 214-229.

Ginting SP, Mahmilia F. 2008. Kambing boerka kambing tipe pedaging hasil persilangan Boer $x$ kacang. Wartazoa 18(3): 115-126.

Gottlieb C, Svanborg K, Eneroth P, Bygdeman M. 1988. Effect of prostaglandins on human sperm function in vitri and seminal adenosine triphosphate content. Fertility and Sterility 49: 322-327.

Hafs HD, Louis TM, Waters RJ, Stellflug JN, Haynes NB. 1974. Increased sperm output of rabbits and bulls treated with PGF2a. Prostaglandins 8: 417-422. 
Hartono M. 2010. Kualitas semen kambing peranakan Boer. Jurnal Penelitian Terapan 10(1): 52-58.

Hashizuma T, Niwa T. 1984. Effect of administration of Prostaglandin F2a on the properties of sperm rich fraction on boar semen. Japan J. Anim. Reprod 39:182-185.

Henney SR, Killian GJ, Deaver DR. 1990. Libido hormone concentrations in blood plasma and semen characteristics in Holstein bulls. Journal of Animal Science 68: 2784- 2792.

Herawati, Widiarso BP. 2003. Pengaruh penambahan prostaglandin F2a terhadap kualitas sperma pada semen kambing yang diencerkan dengan berbagai larutan. Journal of the Indonesian Tropical Animal Agriculture 28(2): 74-78.

Herdis. 2017. Karakteristik semen segar domba garut tipe laga pada tiga waktu penampungan semen. Zoo Indonesia 26(1): 8-19.

Hess M. 2002. The Effect of Oxytocin of Prostaglandin F2a, Oxytocin and Gonadotropin Releasing Hormone on Ejaculate Characteristic in the Dog. Tesis S2. Virginia Polytechnic Institute and State University. Virginia.

Hoesni F. 2013. Pengaruh penggunaan metode thawing yang berbeda terhadap kualitas spermatozoa semen sapi perah berpengencer tris sitrat kuning telur. Jurnal Ilmiah Universitas Batang Hari Jambi 13(4): 118-126.

Ibrahim M. 1988. Influence of oxytocin and prostaglandin on semen characteristics and process of ejaculation in buffalo bulls. Acta Veterinaria Hungarica 82: 3-10.

Ismail M. 2009. Onset dan intensitas estrus kambing pada umuryang berbeda. Jurnal Agroland 16(2): 180-186.

Kozink DM, Estienne MJ, Harper AF, Knight JW. 2002. The effect of lutalyse on the training of sexually in experienced boars for semen collection. Theriogenology 58: 1039-1045.

Kreider JL, Ogg WL, Turner JW. 1981. Influence of prostaglandinf 2 alpha on sperm production and seminal characteristics of the stallion. Prostaglandins 22: 903-913.

Lestari, Ihsan MN, Isnaini N. 2014.Pengaruh waktu simpan semen cair segar denga pengencer Andromed pada suhu ruang terhadap kualitas semen kambing boer. Jumal Temak Tropika 15(1): 43-44.

Levis DG, Reicks DL. 2005. Assessment of sexual behavior and effect of semen collection pen design and sexual stimulation of boars on behavior and sperm output: A review. Theriogenology 63: 630-642.

Masoumi R, Towhidi A, Nejati-Javaremi A, Nabizadeh H, Zhandi M. 2008. Clprostenol injection improves characteristics in low libido Iranian Holstein bulls. Pakistan Journal of Biological Sciences 11(7): 1027-1031.

Masoumi R, Towhidi A, Javaremi AN, Nabizadeh H, Zhandi M. 2011. Influence of PGF2a on semen quality and libido in Holstein bulls. Turkish Journal of Veterinary and Animal Sciences 35(1): 1-6.

Mughniati S, Sari DK, Rendrawan D, Rahim L. 2018. Pengaruh ekstrak biji kapuk (Ceiba pentandra gaertn) sebagai obat kontrasepsi terhadap kualitas spermatozoa pada kucing lokal (Felis domestica). Jurnal Riset Veteriner Indonesia 2(1): 27-34.

Nasich M. 2011. Produktivitas kambing hasil persilangan antara pejantan Boer dengan induk lokal (PE) periode prasapih. JumalTernak Tropika 12(1): 55-62.

Olfati A, Moghaddam GH, Daghigh-Kia H, KaramiShabankareh H. 2013. Effects of prostaglandin F2a treatment on semen characteristics of crossbred rams in the non-breeding season. Journal of Cell and Animal Biology 7(2): 16-20.

Prestiya A, Siregar TN, Wahyuni S, Sari EM, Hafizuddin, Panjaitan B. 2020. Pengaruh pemberian PGF2a dalam pengencer Andromed terhadap peningkatan motilitas spermatozoa kambing Nubian. Jurnal Agripet 20(1): 32-37.

Schlegel W, Rotermund S, Farber G, Nieschlag E. 1981. The influence of prostaglandin on sperm motility. Prostaglandins 21(1): 87-99.

Saifudin M, Isnaini N, Yekti APA, Susilawati T. 2018.Tingkat keberhasilan inseminasi buatan menggunakan semen cair menggunakan media pengencer tris aminomethan kuning telur pada sapi persilangan ongole. Jurnal Ternak Tropika 19(1): 60-65.

Sari EM, Tanjung S, Sari DR, Akmal M, Siregar TN, Thasmi CN. 2019. The improvement of semen quality and testosterone level of bali cattle after prostaglandin $\mathrm{f}_{2} \mathrm{a}$ administration. Jurnal Kedokteran Hewan 13(4): 79-82.

Sieme H, Troedsson MHT, Weinrich S, Klug E. 2004. Influence of exogenous $\mathrm{GnRH}$ on sexual behavior and frozen thawed semen viablity in stallions during the non-breeding season. Theriogenology 61: 159-171. 
Siregar TN, Akmal M, Wahyuni S, Tarigan H, Mulyadi, Nasution I. 2014. Pemberian ekstrak vesikula seminalis meningkatkan kualitas spermatozoa tetapi tidak memengaruhi konsentrasi spermatozoa dan testosteron tikus putih. Jurnal Kedokteran Hewan 8(2):90-93.

Sujoko H, Setiadi MA, Boediono A. 2009. Seleksi spermatozoa domba garut dengan metode sentrifugasi gradien densitas percoll. Jurnal Veteriner 10(3): 125-132.

WHO. 1999. Laboratory Manual for The Examination of Human Semen and SpermCervical Mucus Interaction. 4th ed. Cambridge University Press. England. p35-42. 